Рекомендована д. фрармац. наук, профр. Т. А. Грошовим

УДК 615.15:316.3:34]-048.34

DOI 10.11603/2312-0967.2018.1.8602

\title{
СТАН І ПРОБЛЕМИ НОРМАТИВНО-ПРАВОВОГО ПОЛЯ ФОРМУВАННЯ СОЦІАЛЬНО-ВІДПОВІДАЛЬНОЇ ПОВЕДІНКИ ФАРМАЦЕВТИЧНИХ ФАХІВЦІВ (ОСВІТНІЙ ТА СПЕЦІАЛЬНИЙ РІВЕНЬ)
}

\author{
(c) Н. О. Ткаченко ${ }^{1}$ Б. П. Громовик², О. Г. Алексєєв ${ }^{1}$
}

\author{
Запорізький державний медичний університет ${ }^{1}$ \\ Львівський національний медичний університет імені Данила Галицького \\ tkachenkonat2@gmail.com,hromovyk@gmail.com
}

\begin{abstract}
Мета роботи. Визначення повноти і змістовності чинної нормативно-правової бази (НПБ) освітнього і спеціального рівня моделі правового поля фрормування системи соціально-відповідальної поведінки (СВП) фрармацевтичних фахівців (ФФ), а також опрацювання пропозицій щодо оптимізації зазначеної НПБ.

Матеріали і методи. Матеріалом дослідження були нормативно-правові акти (НПА), які регламентують СВ, фрармацевтичну освіту та діяльність фрармацевтичних організацій (ФО). У роботі використано методи інформаційного пошуку, систематизації, контент-аналізу, порівняння та узагальнення.

Результати й обговорення. Проаналізовано НПБ моделі правового поля срормування системи СВП ФФ упродовж всього життєвого професійного циклу за двома критеріями: ієрархічним принципом (Закони України, Постанови КМ України, накази МОЗ України) та регулюванням відносин у системі СВП ФФ на освітньому і спеціальному рівнях. Окреслено проблемні питання зазначеної НПБ та визначено заходи з її вдосконалення.

Висновки. На підставі аналізу НПА різної ієрархії визначені проблемні питання у правовому полі на освітньому та спеціальному рівнях формування СВП ФФ, що зумовлюють труднощі ефективної реалізації СВ ФО. Сфрормульовано заходи щодо вдосконалення НПБ щодо регулювання діяльності фрармацевтичної галузі та фрормування СВП усіх ії суб’єктів.
\end{abstract}

Ключові слова: соціальна відповідальність; фрармацевтичний фрахівець; фрармацевтична організація; фармацевтична діяльність; нормативно-правові акти.

Вступ. Фармацевтичну організацію (ФО) слід розглядати як систему, в якій тісно перетинаються економічні, правові, соціальні, екологічні й інші процеси, які впливають на її функціонування та розвиток. Сьогодні значної уваги набуває саме соціальний аспект усіх процесів ФО, що значною мірою зумовлений соціальною орієнтацією фрармацевтичної галузі (ФГ) та впровадженням концепції соціальної відповідальності (СВ) у діяльність ФО [1].

Процес впровадження й розвитку СВ ФО розпочинається з базового рівня - СВ особистості, позаяк відповідальність покладається на конкретних осіб, 3 яких складається ФО. Формування СВ фрармацевтичного фрахівця (ФФ) відбувається впродовж усього його профресійного життя, а фундаментальним принципом СВ $€$ дотримання правових і законодавчих норм діяльності ФО з поєднанням активних дій за межами норм, визначених законом та прийняття на себе додаткових, добровільних зобов'язань перед суспільством [2].

Питання СВ у фрармації є предметом дослідження таких вчених, як А. А. Котвіцької, Ю. С. Братішко, О. В. Посилкіної, Є. Г. Книша [3, 4, 5, 6] та ін. Але, зважаючи на значний науковий доробок, недостатньо опрацьованими залишаються питання нормативно-правового забезпечення процесу фрормування соціально-відповідальної поведінки (СВП) ФФ як у процесі отримання професійної освіти, так і в практичній діяльності.

У попередньому нашому дослідженні опрацьовано модель правового поля формування системи СВП ФФ упродовж всього життєвого професійного циклу, яка є складною, багаторівневою системою з розподілом 27 основних нормативно-правових актів (НПА) за двома критеріями: ієрархічним принципом (Закони і Кодекси України, міжнародні стандарти (МС), Постанови КМ України, накази МОЗ України) та за регулюванням відносин у системі СВП ФФ (базового, освітнього, спеціального рівнів) (рис.1). Основну увагу приділено базовому рівню правового поля, у рамках якого встановлюються загальні правила суспільних відносин під час господарської діяльності та $€$ засадами фрормування СВ у всіх галузях економіки, зокрема у ФО. При цьому визначені проблеми у правовому полі цього рівня формування СВП ФФ, що зумовлюють труднощі ефективної реалізації СВ ФО [7].

ISSN 2312-0967. Фармацевтичний часопис. 2018. № 1 
Тому метою цього фррагмента дослідження було визначення повноти і змістовності чинної нормативно-правової бази (НПБ) освітнього і спеціального рівня моделі правового поля формування системи СВП ФФ, а також опрацювання пропозицій щодо оптимізації зазначеної НПБ.

Матеріали і методи. Матеріал дослідження - нормативно-правові акти (НПА), які регламентують СВ фармацевтичну освіту та діяльність ФО. У роботі використано методи інформаційного пошуку, систематизації, контент-аналізу, порівняння та узагальнення.

Результати й обговорення. На освітньому рівні моделі правового поля формування СВП ФФ відбувається розвиток системи неперевної фрармацевтичної освіти (НФО) і регулювання процесів формування професійних компетенцій в рамках таких освітніх НПА (рис. 1):

1. Закон України «Про освіту» [8], яким означено загальні освітні, виховні, морально-етичні основи майбутнього ФФ; закріплено пріоритетність освіти в державі та основні засади державної політики у сфері освіти; визначено структуру, стандарти освіти, кваліфрікації, освітні програми, компетентнісний підхід на всіх рівнях навчання. Однак для запровадження усіх положень цього НПА необхідні:

- час, кошти, підтримка суспільства, зміна свідомості педагогів й методик навчання;

- ухвалення та впровадження НПА про середню та професійну освіту;

- створення або реорганізація органів управління, передбачених новим освітнім законодавством.

2. Закон України «Про вищу освіту» [9], який встановлює основні правові, організаційні, фрінансові засади фрункціонування системи вищої освіти (у т. ч. фрармацевтичної) 3 метою підготовки конкурентоспроможного людського капіталу, самореалізації особистості, забезпечення потреб суспільства, ринку праці та держави у кваліфікованих фрахівцях, фрормування відповідальної поведінки кожного суб'єкта відносин. В рамках цього НПА створюються умови для посилення співпраці державних органів і суб'єктів фрармацевтичного підприємництва (ФП) з ВН3 (на принципах автономії ВНЗ), відбувається поєднання освіти з наукою та виробництвом.

Проте сьогодні існують труднощі в ефрективній реалізації зазначених положень Закону, зокрема [10]: відсутність єдності та консолідованості у середовищі фрармацевтичної академічної спільноти щодо спеціальностей, освітніх рівнів і ступенів, змісту підготовки та форм навчання здобувачів університетської фрармацевтичної освіти (УФО); неадекватність освітніх програм потребам фрармацевтичної практики; комерціалізація УФО внаслідок неналежного фрінансування державних вишів; неможливість здобувачами УФО набувати необхідних знань і навичок, а науково-педагогічними працівниками проводити пристойні наукові розробки внаслідок неналежного матеріально- технічного забезпечення через неадекватне фрінансування державних вишів; здобуття більшістю студентів УФО за заочною формою навчання, яка в розвинутих країнах у підготовці ФФ відсутня; низький рівень оплати праці та неефективність механізмів заохочення науково-педагогічних працівників УФО; неналежний фраховий рівень низки викладачів дипломної й післядипломної УФО; відсутність відповідальності вишів фрармацевтичного спрямування за кінцеві результати освітньої діяльності. При цьому не розвинені достатньою мірою незалежні форми й механізми участі роботодавців і громадських організацій (ГО) фрармацевтичного спрямування у вирішенні питань освітньої політики, зокрема в процесах незалежної суспільної оцінки якості УФО, адже більша частина суб'єктів ФП не зацікавлені у співпраці з вишами і зовсім не бажають брати на себе відповідальність за майбутнє ФГ. Необхідна зміна парадигми відносин між роботодавцями й вишами.

3. Постанова КМ України від 23.11.11 р. № 1341 [11], якою пояснюється процедура введення і застосування європейських стандартів та принципів забезпечення якості освіти з урахуванням вимог ринку праці до компетентностей фахівців, а також забезпечується гармонізація норм законодавства у сфері освіти та соціально-трудових відносин. На жаль, дане положення, у зв'язку з відсутністю ефективної взаємодії сорери освітніх послуг та ринку праці, сьогодні не виконується.

4. Наказ МОЗ України від 19.09.1996 р. № 291 [12], який визначає основні правові, організаційні й фрінансові засади інтернатури як обов'язкової форми НФО. Проте відсутність організованої системи працевлаштування ФФ-випускників на бази стажування та юридичної відповідальності з боку ФО-баз спеціалізації, а також неналежне ставлення провізорів-інтернів до цього етапу НФО зводить нанівець мету заочної фрорми інтернатури. При цьому очна фрорма інтернатури відбувається за навчальною програмою, яка здебільшого дублює додипломну підготовку провізорів та не за Європейською кредитною трансферно-накопичувальною системою, що свідчить про розбіжності і відсутності спадковості у до- і післядипломному освітньому періодах НФО.

3 метою підвищення професійної майстерності, відповідальності за ефективність та якість роботи, відповідно до наказів МОЗ України № 166 від 22.07.1992 р. та № 818 від 12.12.2006 р. [13, 14] ФФ періодично проходить атестацію. Вона $є$ важливою фрормою мотивації, спрямованою на вдосконалення діяльності ФО усіх фрорм власності, що займаються фрармацевтичною діяльністю (ФД). На жаль, атестація ФФ сьогодні для більшості суб'єктів ФП не є формою матеріального та морального стимулювання, адже вона тільки збільшує затратні статті ФО, що, у свою чергу, спричиняє незацікавленість ФФ. Необов'язковий характер носить атестація на присвоєння кваліфрікаційної

ISSN 2312-0967. Pharmaceutical review. 2018. № 1 
Фармацевтичний менеджмент, маркетинг та логістика

Pharmaceutical management, marketing and logistics

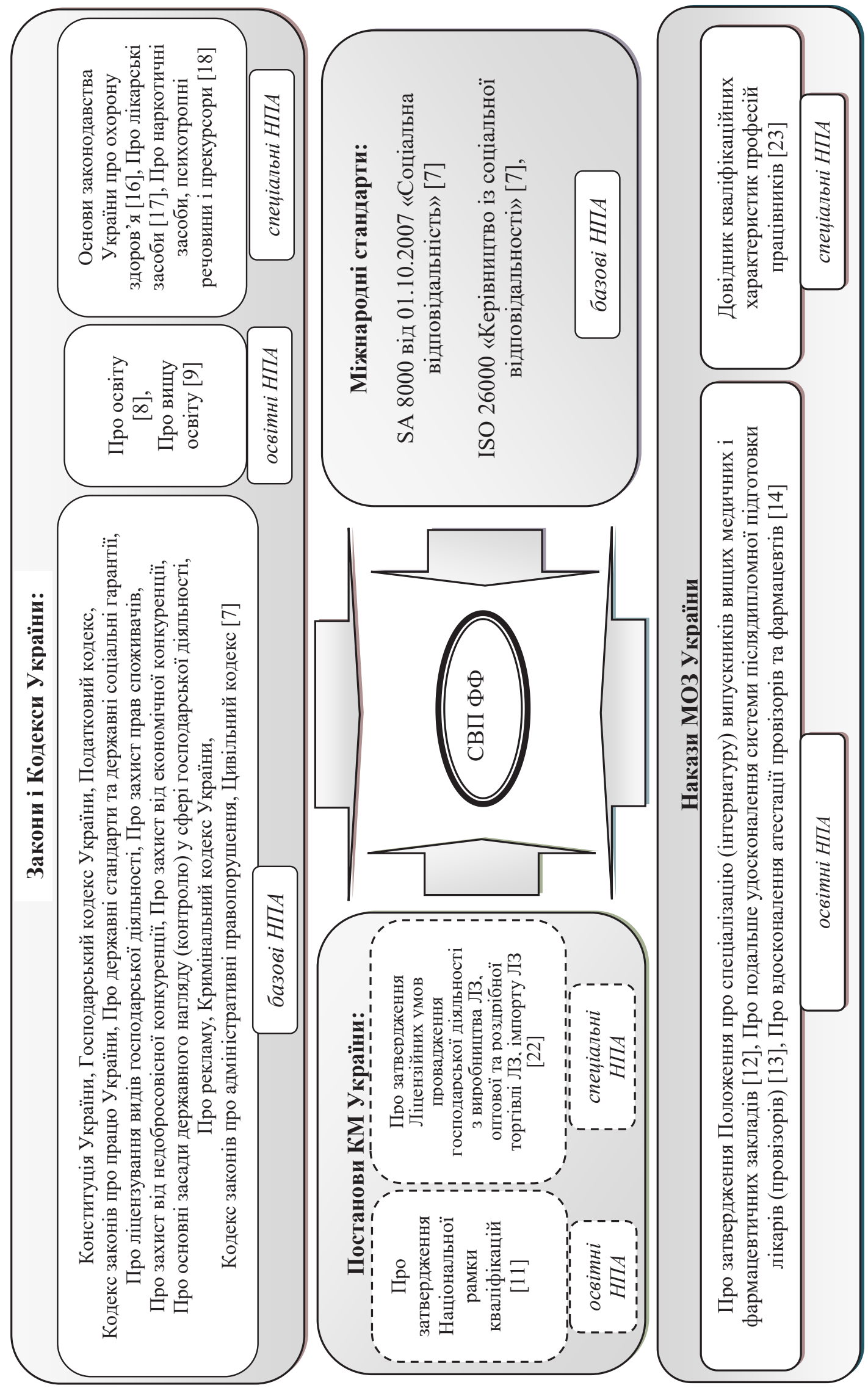

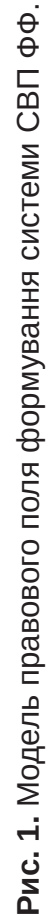

ISSN 2312-0967. Фармацевтичний часопис. 2018. № 1 
категорії та на підтвердження кваліфрікаційної категорії, як наслідок - дотримуються встановлених норм лише комунальні ФО. При цьому в порядку атестації провізорів на підтвердження кваліфрікаційної категорії, на відміну від лікарів [15], відсутнє чітке положення про те, що вона проводиться без співбесіди з провізором на основі поданих документів.

На спеціальному рівні моделі правового поля фрормування СВП ФФ регулюються власне різні аспекти фармацевтичної діяльності (ФД) та суспільні відносини ФО і ФФ. До основних спеціальних НПА, в яких зазначені основні правові засади різних аспектів ФД, відносяться (рис. 1):

1. Закон України «Основи законодавства України про охорону здоров'я» [16], який визначає суб'єктів медичної діяльності й ФД (особи, які мають відповідну спеціальну освіту і відповідають єдиним кваліфікаційним вимогам), профресійні права, пільги та обов'язки медичних і ФФ, ссреру їх відповідальності. Тобто, зазначений НПА «закладає» фрундамент правового регулювання процесів, пов'язаних із формуванням СВП ФФ.

На жаль, в цьому Законі $€$ понятійно-категорійний апарат стосовно медичної діяльності, але відсутні дефініції «ФД» та організаційно-правовий механізм її здійснення, що залишається приводом різних тлумачень науковців, правознавців й управлінців. Назріла термінова необхідність в опрацюванні Закону, який буде визначати організаційно-правові, економічні та соціальні засади ФД, окреслювати поле й вектор розвитку СВП з урахуванням чинних просресійних ролей ФФ.

2. Закон України «Про лікарські засоби» [17], який регулює правовідносини, пов'язані із створенням, реєстрацією, виробництвом, контролем якості та реалізацією лікарських засобів (ЛЗ), визначає права та обов'язки підприємств, установ, організацій і громадян, а також повноваження у цій сорері органів виконавчої влади й посадових осіб. Відповідно із ст. 3, держава сприяє науковим дослідженням, створенню та впровадженню нових технологій, розвитку виробництва високоефективних та безпечних лз, забезпеченню потреб населення ліками належної якості та в необхідному асортименті шляхом ведення Державного реєстру Лз України із забезпеченням публічного доступу до нього осіб, здійснення відповідних загальнодержавних програм, пріоритетного фрінансування, надання пільгових кредитів, встановлення податкових пільг тощо. 3 метою реалізації права громадян України на охорону здоров'я держава повинна забезпечити доступність найнеобхідніших л3, захист громадян у разі заподіяння шкоди їх здоров'ю внаслідок застосування Лз за медичним призначенням, а також встановлювати пільги і гарантії окремим групам населення та категоріям громадян щодо забезпечення їх ЛЗ в разі захворювання. Особи, винні в порушенні законодавства про Л3, несуть дисциплінарну, адміністративну, цивільно-правову або кримінальну відповідальність згідно із законодавством (ст. 27).
Серед основних порушень Закону України «Про лікарські засоби»: фральсифрікація ЛЗ, недотримання нормативних умов зберігання ЛЗ, недотримання санітарних норм і гігієнічних нормативів, відпуск рецептурних Лз без рецепта, здійснення ФД особами, що не відповідають кваліфікаційним вимогам.

3. Закон України «Про наркотичні засоби, психотропні речовини і прекурсори» [18], який визначає правові та організаційні засади державної політики щодо обігу в Україні контрольованих засобів і речовин, встановлює порядок державного контролю, повноваження органів виконавчої влади, права та обов'язки фрізичних і юридичних осіб у сфері їх обігу. Відповідно до цього Закону, заходами контролю за обігом $€$ : визначення основних умов, вимог, правил і системи заходів, пов'язаних з обігом контрольованих засобів і речовин в Україні; ліцензування відповідних видів діяльності; запровадження системи дозволів та контролю за дотриманням дозвільних документів; подання в установленому порядку суб'єктами господарювання до центрального органу виконавчої влади, що реалізує державну політику у сорері обігу даних речовин, звітів про діяльність; подання статистичних даних щодо фактичного обігу; здійснення контролю за виконанням вимог та умов, передбачених законодавством; відпуск фрізичним особам наркотичних засобів, психотропних речовин лише за рецептом лікаря і відповідно до медичних показань; створення системи звітної та облікової документації у даній сорері; встановлення спеціальних вимог до кваліфрікації працівників та обмежень, пов'язаних 3 виконанням окремих видів діяльності (робіт, професій, служби); обмеження реклами про наркотичні засоби і психотропні речовини; встановлення спеціальних вимог щодо зберігання та гранично допустимої кількості наркотичних засобів, психотропних речовин; запровадження відповідальності за порушення законодавства про наркотичні засоби, психотропні речовини і прекурсори та ін.

Проте сьогодні у судовій та іншій правозастосовній практиці немає відповіді на питання щодо регулювання обігу л3, що містять кодеїн і ряд інших препаратів 3 підконтрольними речовинами, правового режиму, відповідно до якого має здійснюватися обіг комбінованих Л3, що містять малу кількість підконтрольних речовин, які не вилучаються легкодоступним способом [19, 20]. Крім того, назріла гостра потреба у конкретних НПА, що регламентують діяльність, пов'язану з профрілактикою наркоманії. Сучасний розвиток НПБ характеризується тим, що місце профрілактики серед інших юридичних понять не визначене, тобто правова її основа не розроблена і законодавче забезпечення державної системи профілактики наркоманії практично відсутнє [21].

4. Постанова КМ України № 929 від 30.11.2016 р. [22], яка встановлює вичерпний перелік вимог,

ISSN 2312-0967. Pharmaceutical review. 2018. № 1 
Фармацевтичний менеджмент, маркетинг та логістика Pharmaceutical management, marketing and logistics

обов'язкових для виконання ФО з провадження господарської діяльності з виробництва ЛЗ, оптової, роздрібної торгівлі Л3, імпорту ЛЗ (крім активних фрармацевтичних інгредієнтів). Відповідно до цього НПА, суб'єкт господарювання зобов'язаний вживати заходів для забезпечення якості Лз під час відповідного виду господарської діяльності, повинен мати кваліфрікований персонал у кількості, що дає змогу якісно виконати всі завдання. У наявності повинні бути затверджені штатний розклад та посадові інструкції працівників, в яких вказані основні функції, повноваження, профресійні знання, компетенції та інші вимоги до працівників.

На практиці ж відмічається велика кількість невідповідностей вимогам зазначеного вище НПА суб'єктів ФП і як наслідок, відмова у видачі дозволу на здійснення ФД. Серед невідповідностей значними $€$ відсутність управлінсько-організаційних документів 3 кадрових питань ФО, фральсифрікація і недостовірність документів, наявність серед працюючого персоналу 3 відпуску лз осіб, що не відповідають кваліфрікаційним вимогам, невідповідний кваліфікаційний рівень управлінського персоналу. Виконання і дотримання основних вимог ускладнюється дефіцитом ФФ, який виник у результаті збільшення кількості суб'єктів ФП за останні роки. Ускладнюють ситуацію також зниження попиту серед роботодавців на висококваліфікованих ФФ, велика плинність кадрів в оптовому і роздрібному сегментах фрармацевтичного ринку.

5. Наказ МО3 України від 29.03.2002 р. № 117 [23], який на сьогодні пояснює питання кваліфікаційних вимог до ФФ та використовується для правильного розподілу персоналу згідно з фрахом і кваліфрікацією, визначення завдань, обов'язків і відповідальності працівників галузі О3.

Проте нині існують розбіжності між Довідником кваліфрікаційних характеристик та Ліцензійними умовами провадження господарської діяльності з виробництва Л3, оптової та роздрібної торгівлі Л3, імпорту Л3 (крім активних фрармацевтичних інгредієнтів) [22] стосовно вимог, які висуваються до завідувача аптеки. Також МO3 України та/або Міністерством праці та соціальної політики України не запропоновано критеріїв, що повинні враховуватись при складанні посадових інструкцій ФФ.

Підсумовуючи результати досліджень, ми сфрормулювали заходи 3 вдосконалення національної НПБ щодо регулювання ФД та фрормування СВП усіх ії суб'єктів.

По-перше, державі потрібно взяти на себе відповідальність за свій напрямок регулювання ФД. Необхідно посилити контрольну функцію, адже більшість НПА розроблено, затверджено та імплементовано. щодо ФП, як соціально значущого сектора галузі охорони здоров'я, то державний контроль повинен бути постійним, безперервним і становити виняток у можливих майбутніх мораторіях щодо зупинення державного нагляду.
Терміново потрібно розробити й прийняти закон «Про фрармацевтичну діяльність», в якому на законодавчому рівні буде закріплена десрініція «ФД», організаційно-правовий механізм її здійснення, визначені механізми СВ, як обов'язкової й невіддільної складової суб'єктів ФП, НФО і науки, ГО фрармацевтичного спрямування, ФФ, модель суспільних відносин на основі комунітарної СВ, а також персонісрікація СВ. Також негайно потрібно стандартизувати ФД. Стандарти повинні бути доведені до алгоритму із зображення мети, дій, засобів НПБ, очікуваних результатів.

Треба вдосконалити роботу системи органів захисту інтересів суб'єктів ФП, а саме: покращити матеріально-технічне та кадрове забезпечення, викорінити корупційні прояви, вдосконалити координацію діяльності між усіма органами в процесі боротьби 3 недобросовісною конкуренцією.

По-друге, регуляторним органам держави слід частіше використовувати потенціал ГО фрармацевтичного спрямування у вирішенні проблемних питань в освіті, практичній діяльності ФО, нормотворчості тощо. Необхідно розробити систему мотивації активності ГО в рамках комунітарної СВ. Потрібно проводити інформаційно-роз'яснювальну роботу, спрямовану на висвітлення переваг добросовісної конкуренції як для підприємців, так і для споживачів, порядку захисту їх від недобросовісної конкуренції.

Важливим завданням $є$ визначення та обґрунтування правового й управлінсько-економічного забезпечення збалансування інтересів державного регулювання і саморегулювання учасників фрармацевтичного ринку через прийняття відповідного НПА [24].

По-третє, $з$ метою введення європейських стандартів і принципів забезпечення якості освіти з урахуванням вимог ринку праці до компетентностей ФФ забезпечити гармонізацію норм законодавства у сорері освіти та соціально-трудових відносин, розробити механізми ефрективної взаємодії ссрери освітніх послуг та ринку праці, удосконалити навчальні програми на до- та післядипломному рівні з урахуванням зазначених проблемних питань. Доцільно переглянути НПА, що стосуються кадрового забезпечення, вимог до ФФ, фрармацевтичних посад, нормування робочого часу ФФ тощо. Опрацювати нову парадигму відносин між роботодавцями й вишами.

Перспективним напрямом гармонізації й оптимізації сорери профресійної освіти і ринку праці є створення єдиної бази даних стосовно ФФ (поєднання додипломної й післядипломної інорормації й обліку).

Висновки. На підставі аналізу НПА різної ієрархії визначені проблемні питання у правовому полі на освітньому та спеціальному рівнях фрормування СВП $Ф Ф$, що зумовлюють труднощі ефективної реалізації СВ ФО.

Сорормульовано заходи щодо вдосконалення НПБ щодо регулювання діяльності фармацевтичної галузі та орормування СВП усіх її суб'єктів.

ISSN 2312-0967. Фармацевтичний часопис. 2018. № 1 


\title{
СОСТОЯНИЕ И ПРОБЛЕМЫ НОРМАТИВНО-ПРАВОВОГО ПОЛЯ ФОРМИРОВАНИЯ СОЦИАЛЬНО- ОТВЕТСТВЕННОГО ПОВЕДЕНИЯ СПЕЦИАЛИСТОВ ФАРМАЦИИ (ОБРАЗОВАТЕЛЬНЫЙ И СПЕЦИАЛЬНЫЙ УРОВЕНЬ)
}

\author{
Н. А. Ткаченко ${ }^{1}$ Б. П. Громовик ${ }^{2}$, А. Г. Алексеев ${ }^{1}$ \\ Запорожский государственный медицинский университет ${ }^{1}$ \\ Львовский национальный медицинский университет имени Данила Галицкого 2 \\ tkachenkonat2@gmail.com,hromovyk@gmail.com
}

\begin{abstract}
Цель работы. Определение полноты и содержательности действующей нормативно-правовой базы (НПБ) образовательного и специального уровней модели правового поля формирования системы социальноответственного поведения (СОП) специалистов фрармации (СФ), а также разработка предложений по оптимизации указанной НПБ.

Материалы и методы. Материалом для исследования были НПА, регламентирующие социальную ответственность, фрармацевтическое образование и деятельность фрармацевтических организаций (ФО). В ходе работы использованы методы информационного поиска, систематизации, контент-анализа, сравнения и обобщения.

Результаты и обсуждение. Проанализирована НПБ модели правового поля фрормирования СОП СФ на протяжении всего жизненного цикла профрессионального развития за двумя критериями: иерархическим принципом (Законы Украины, Постановления КМ Украины, приказы МОЗ Украины) и регулированием отношений в системе СОП СФ на образовательном и специальном уровнях. Очерчен ряд проблемных вопросов указанной НПБ и определены мероприятия по ее усовершенствованию.

Выводы. На основе анализа НПА различной иерархии определены проблемные вопросы в правовом поле на образовательном и специальном уровнях формирования СОП СФ. Сфрормулированы меры по совершенствованию НПБ по регулированию деятельности фармацевтической отрасли и фоормированию социально-ответственного поведения всех ее субъектов.
\end{abstract}

Ключевые слова: социальная ответственность; специалист фрармации; фрармацевтическая организация; фрармацевтическая деятельность; нормативно-правовые акты.

\section{THE STATE AND PROBLEMS OF THE NORMATIVE-LEGAL FIELD OF FORMING SOCIAL AND RESPONSIBLE BEHAVIOR OF PHARMACY SPECIALISTS (EDUCATIONAL AND SPECIAL LEVEL)}

\author{
N. O. Tkachenko ${ }^{1}$, B. P. Hromovyk ${ }^{2}$, O. N. Aleksieiev ${ }^{1}$ \\ Zaporizhzhya State Medical University, Zaporizhzhya ${ }^{1}$ \\ Danylo Halytsky Lviv National Medical University, Lviv² \\ tkachenkonat2@gmail.com,hromovyk@gmail.com
}

The aim of the work. Determination of the completeness and content of the current regulatory and legal framework of the educational and special levels of the model of the legal field for the formation of a system of socially responsible behavior of pharmacists, and the development of proposals for the optimization of this regulatory framework.

Materials and Methods. The material for the study was normative legal acts regulating social responsibility, pharmaceutical education and activities of pharmaceutical organizations. In the course of our work we used the methods of information retrieval, systematization, content analysis, comparison and generalization.

Results and Discussion. We have analyzed the legal framework of the model of the legal field for the formation of socially responsible behavior of pharmacy specialists throughout the life cycle of professional development for two criteria: hierarchical principle (Laws of Ukraine, Decrees of the Cabinet of Ministers of Ukraine, orders of the Ministry of Health of Ukraine) and regulation of relations in the system of socially responsible behavior of pharmacy specialists at the educational and special levels. We have identified a number of problematic issues of this regulatory framework and measures to improve it.

Conclusions. Based on the analysis of regulatory legal acts of different hierarchies, we identified problematic issues in the legal field at the educational and special levels of the formation of socially responsible behavior of pharmacists. We have formulated measures to improve the regulatory and legal framework for regulating the activities of the pharmaceutical industry and the formation of socially responsible behavior of all its subjects.

Key words: social responsibility; pharmacists; pharmaceutical organization; pharmaceutical activity; normative legal acts.

ISSN 2312-0967. Pharmaceutical review. 2018. № 1 
Фармацевтичний менеджмент, маркетинг та логістика Pharmaceutical management, marketing and logistics

\section{Список літератури}

1. Новий міжнародний стандарт із соціальної відповідальності ISO 26000 [Електронний ресурс]. - Режим доступу : http://www.bcdst.kiev.ua/index.php/news/1- latestnews $/ 56$

2. Ткаченко Н. О. Концептуальний аналіз соціальної відповідальності особистості та її інтегрування у фрармацевтичну практику / Н. О. Ткаченко, Б. П. Громовик // Актуальні питання фрармацевтичної і медичної науки та практики. - 2017. - № 3 (25). - С. 342-348.

3. Черкашина А. В. Дослідження сучасного стану соціальної відповідальності найбільших аптечних мереж міста Харкова / А. В. Черкашина, А. А. Котвіцька // Управління , економіка та забезпечення якості в фрармації. - 2014. - № 2 (34) . - С. 36-41.

4. Братішко Ю. С. Зовнішня соціальна відповідальність фармацевтичних компаній / Ю. С. Братішко // Young Scientist. - 2016. - № 4(31). - C. 276-280.

5. Посилкіна О. В. Формування системи показників оцінки соціальної відповідальності фрармацевтичного бізнесу / О. В. Посилкіна, Ю. С. Братішко, Г. В. Кубасова // Клінічна фрармація. - 2015. - Т.19, № 2. - С. 4-8.

6. Ткаченко Н. О. Сучасний стан і характеристика соціальної відповідальності підприємницької діяльності / Н. О. Ткаченко, Н. М. Червоненко, Є. Г. Книш // Запорожский медицинский журнал. - 2013. - № 2. - С. 76-82. 7. Ткаченко Н. О. Моделювання правового поля соціально-відповідальної поведінки фрармацевтичних фрахівців / Н. О. Ткаченко, Б. П. Громовик // Актуальні питання фрармацевтичної і медичної науки та практики. - 2018. № 1 (26). - C. 104-111.

8. Про освіту: Закон України від 05.09.17 р. №2145-VIII [Електронний ресурс]. - Режим доступу : http://zakon3. rada.gov.ua/laws/show/2145-19.

9. Про вищу освіту: Закон України від 06.09.14 р. № 1556-VII [Електронний ресурс]. - Режим доступу : http://zakon2.rada.gov.ua/laws/show/1556-18.

10. Громовик Б. П. Університетська фрармацевтична освіта України: проблемні питання / Б. П. Громовик // Підготовка спеціалістів фрармації в рамках концепції «Навчання протягом життя (Life Long Learning)»: наука, освіта, практика / Training Specialists Of Pharmacy In Concept «Life Long Learning»: Science, Education, Practice: матеріали I наук.-практ. інтернет-консеренції 3 міжнар. участю (16-17 трав. 2017 р., м. Харків) / ред. кол. : В. М. Толочко та ін. - Х. : НФаУ, 2017. - С. 94-96.

11. Про затвердження Національної рамки кваліфрікацій: Постанова КМ України від 23.11.11 р. № 1341 № 1556-VII [Електронний ресурс]. - Режим доступу : http://zakon3. rada.gov.ua/laws/show/1341-2011-\%D0\%BF.

12. Про затвердження Положення про спеціалізацію (інтернатуру) випускників вищих медичних і фрармацевтичних закладів: наказ МОЗ України від 19.09.96 р. № 291 [Електронний ресурс]. - Режим доступу : http://zakon2. rada.gov.ua/laws/show/z0696-96.

13. Про подальше удосконалення системи післядипломної підготовки лікарів (провізорів): наказ МОЗ України від 22.07.1992 р. № 166 [Електродний ресурс]. - Режим доступу : http://zakon3.rada.gov.ua/laws/show/z0113-93.
14. Про вдосконалення атестації провізорів та фрармацевтів: наказ МО3 України від 12.12.2006 р. № 818 [Електродний ресурс]. - Режим доступу : http://zakon2. rada.gov.ua/laws/show/z1366-06.

15. Про подальше вдосконалення атестації лікарів МОЗ України від 19.12.1997 р. №359 (редакція від 26.02.2016) [Електродний ресурс]. - Режим доступу : http://zakon2. rada.gov.ua/laws/show/z0014-98.

16. Основи законодавства України про охорону здоров'я: Закон України від 19.11.1992 р. № 2801-XXI [Електронний ресурс]. - Режим доступу : http://zakon3.rada.gov. ua/laws/show/2801-12.

17. Про лікарські засоби: Закон України від 04.04.96 р. № 124/96-ВР [Електронний ресурс]. - Режим доступу : http://zakon3.rada.gov.ua/laws/show/123/96$\% \mathrm{D0} \% \mathrm{~B} 2 \% \mathrm{D} 1 \% 80$.

18. Про наркотичні засоби, психотропні речовини і прекурсори: Закон України від 15.02.1995 р. № 60/95 - ВР [Електронний ресурс]. - Режим доступу : http://zakon5. rada.gov.ua/laws/show/60/95-\%D0\%B2\%D1\%80.

19. Окушко А. В. Особливості доказування порушень встановлених правил обігу наркотичних засобів, психотропних речовин і прекурсорів / А. В. Окушко // Науковий вісник Національної академії внутрішніх справ. - 2017. - №1 (102). - С. 258-267.

20. Відпуск комбінованих препаратів, що містять кодеїн та інші підконтрольні речовини: що має знати аптечний працівник? Державна служба з лікарських засобів та контролю за наркотиками у Тернопільській області [Електронний ресурс]. - Режим доступу : http://region. diklz.gov.ua/control/ter/uk/publish/article/847396;jsessionid =546A42DC51858714B48B7428F1A3D104

21. Про Концепцію реалізації державної політики у ссрері протидії поширенню наркоманії, боротьби з незаконним обігом наркотичних засобів, психотропних речовин і прекурсорів на 2011-2015 роки: Розпорядження КМ України від 13.09.2010 р. №1808-р [Електронний ресурс]. - Режим доступу : http://zakon2.rada.gov.ua/laws/ show/1193-2011-\%D1\%80.

22. Про затвердження Ліцензійних умов провадження господарської діяльності з виробництва лікарських засобів, оптової та роздрібної торгівлі лікарськими засобами, імпорту лікарських засобів (крім активних фрармацевтичних інгредієнтів): Постанова КМ України від 30.11.2016 р. № 929 [Електродний ресурс]. - Режим доступу : http://zakon3.rada.gov.ua/laws/show/929-2016$\% \mathrm{D0} \% \mathrm{BF}$

23. Довідник кваліфрікаційних характеристик: наказ МОЗ України від 29.03.2002 р. № 117 [Електродний ресурс]. - Режим доступу : http://www.moz.gov.ua/ua/portal/ dn_20020329_117.html.

24. Громовик Б. П. Сучасний стан законодавчого забезпечення саморегулювання господарської діяльності та перспективи саморегулювання і державного регулювання фрармацевтичної діяльності в Україні / Б. П. Громовик, О. Б. Панькевич // Фармацевтичний часопис. - 2017. - № 3. - С. $97-104$.

ISSN 2312-0967. Фармацевтичний часопис. 2018. № 1 


\section{References}

1. New International Standard for Social Responsibility ISO 26000. Available from: http://www.bcdst.kiev.ua/index.php/ news/1- latest-news/56.

2. Tkachenko NO, Hromovyk BP. [Conceptual analysis of social responsibility of the person and its integration in pharmaceutical practice]. Aktualni pyt farmats i med nauky i praktyky. 2017;3(25): 342-8. Ukrainian.

3. Cherkashyna AV, Kotvitska AA. [Research of the current state of social responsibility of large pharmacies networks of Kharkiv city]. Upravl, ekonom ta zapezpech yakosti v farmats. 2014;2: 36-41. Ukrainian.

4. Bratishko YuS. [External social responsibility of pharmaceutical companies]. Young Scientist, 2016;4: 27680. Ukrainian.

5. Posylkina OV, Bratishko YuS, Kubasova HV. [Formation of the system of indicators for the assessment of the social responsibility of pharmaceutical business]. Klinichna farmats. 2015;19(2): 4-8. Ukrainian.

6. Tkachenko NO, Chervonenko NM, Knysh EG. [The current state and characteristics of social responsibility of business]. Zaporozhskiy meditsinskiy zhurnal. 2013;2(77): 76-82. Ukrainian.

7. Tkachenko NO, Hromovyk BP. (2018). [Modeling of the legal field formation socially responsible conduct of pharmacy specialists]. Aktualni pyt farmats i med nauky i praktyky.. 2018;1(26): 107-14. Ukrainian.

8. Zakon Ukrainy vid 05.09.2017 № 2145-VIII «About education» Available from: http://zakon2.rada.gov.ua/laws/ show/1060-12. Ukrainian.

9. Zakon Ukrainy vid 06.09.14 № 1556-VII «On Higher Education» Available from: http://zakon2.rada.gov.ua/laws/ show/1556-18. Ukrainian.

10. Hromovyk, B. University Pharmaceutical Education in Ukraine: problematic issues. In: Tolochko V.M. editors. Training Specialists Of Pharmacy In Concept «Life Long Learning»: Science, Education, Practice: materials 1 scientific and practical conference with international participation, 2017 May 16-17; Kharkiv. Kharkiv: National Pharmaceutical University; 2017 p. 94-96.

11. Postanova KM Ukrainy vid 23.11.11 № 1341 «On Approval of the National Qualifications Framework» Available from: http://zakon3.rada.gov.ua/laws/show/13412011-\%D0\%BF. Ukrainian.

12. Nakaz MOZ Ukrainy vid 19.09.1996 №291 «On Approval of the Regulations on the Specialization (Internship) of Higher Medical and Pharmaceutical Institutions Graduates» Available from: http://zakon2.rada.gov.ua/laws/show/ z0696-96. Ukrainian.

13. Nakaz MOZ Ukrainy vid 22.07.1992 №166. «On further improvement of the system of postgraduate training of doctors (pharmacists)» Available from: http://zakon3.rada. gov.ua/laws/show/z0113-93. Ukrainian.
14. Nakaz MOZ Ukrainy vid 12.12.2006 № 818 «On improving the attestation of pharmacists» Available from: http://zakon2.rada.gov.ua/laws/show/z1366-06. Ukrainian. 15. Nakaz MOZ Ukrainy vid 19.12.1997 №359 «On further improving the certification of doctors» Available from: http:// zakon2.rada.gov.ua/laws/show/z0014-98. Ukrainian.

16. Zakon Ukrainy vid 19.11.1992 №2801-XXI «Fundamentals of the Legislation of Ukraine on Health Care» Available from: http://zakon3.rada.gov.ua/laws/ show/2801-12. Ukrainian.

17. Zakon Ukrainy vid 04.04.1996 №124/96-VR «On Medicinal Products» Available from: http://zakon3.rada. gov.ua/laws/show/123/96-\%D0\%B2\%D1\%80. Ukrainian.

18. Zakon Ukrainy vid 15.02.1995 № 60/95-VR «On Circulation of Drugs, Psychotropic Substances, Their Analogs and Precursors in Ukraine». Available from: http:// zakon5.rada.gov.ua/laws/show/60/95-\%D0\%B2\%D1\%80. Ukrainian.

19. Okushko A. [Peculiarities of proving the facts of violating the established regulations for narcotics, psychotropic substances and precursors turnover]. Naukovyi visnyk Natsionalnoi akademii vnutrishnikh sprav. 2017;1(102): 257-67. Ukrainian.

20. Derzhavna sluzhba z likarskykh zasobiv ta kontroliu za narkotykamy u Ternopilskii oblasti [Release of combined medications containing codeine and other controlled substances: what should a pharmacist know?] Available from: http://region.diklz.gov.ua/control/ter/uk/publish/articl e/847396; jsessionid=546A42DC51858714B48B7428F1A 3D104. Ukrainian

21. Postanova KM Ukrainy vid 13.09.2010 №1808-p «On the Concept of the implementation of the state policy in the area of combating the spread of drug addiction, combating illicit trafficking in narcotic drugs, psychotropic substances and precursors for 2011-2015» Available from: http://zakon2.rada.gov.ua/laws/show/1193-2011-\%D1\%80. Ukrainian.

22. Postanova KM Ukrainy vid 30.11.2016 №929 «On the approval of licensing conditions for the introduction of economic activities for the production of pharmaceuticals, wholesale and retail trade in medicines, the import of medicines» Available from: http://zakon3.rada.gov.ua/laws/ show/929-2016-\%D0\%BF. Ukrainian.

23. Nakaz MOZ Ukrainy vid 29.03.2002 №117 «Directory of qualifying characteristics» Available from: http://www.moz. gov.ua/ua/portal/dn_20020329_117.html. Ukrainian.

24. Hromovyk BP, Pankevych OB. [The current state of economic activity legislative provision of self-regulation and prospects of self-regulation and public regulation of pharmaceutical activity in Ukraine]. Farmats chasopys. 2017;3: 97-104. Ukrainian. 